\title{
INVESTASI SWASTA DI INDONESIA
}

\author{
Zuhairan Y. Yunan \\ Ikatan Sarjana Ekonomi Indonesia \\ zuhairan@gmail.com
}

\begin{abstract}
The result of cointegration test shows that the determinant variables in the model with private investment which means, in the long term direction of movement of independent variables with dependent variables. Based on statistical tests, Error Correction Model (ECM) private investment, coefficient of national income variable on short-term is significant and have positive signs. The coefficient of variable error correction term $\left(E C T_{t-1}\right)$ are statistically significant at $99 \%$ confidence level and has a negative sign. Coefficient $E C T_{t}$ variable is negative means that model in the short term under long-term equilibrium, so that the balance of short-term adjustment process towards long run equilibrium moves upward direction. In the long-term, the economic crisis affects private investment and negative sign.
\end{abstract}

Keywords: Private Investment; Error Correction Model; Cointegration

\begin{abstract}
Abstrak
Hasil uji kointegrasi menunjukkan bahwa variabel penentu dalam model investasi swasta memiliki hubungan jangka panjang dengan pergerakan variabel independen bersamaan variabel dependen. Berdasarkan uji statistik, model koreksi kesahalan pada investasi swasta, koefisien variabel pendapatan nasional dalam jangka pendek ialah signifikan dan positif. Koefisien pada variabel term koreksi kesalahan $\left(E C T_{t-1}\right)$ secara signifikan berpengaruh pada tingkat 99\% dan memiliki tanda negatif. Koefisien variabel $E C T_{t}$ memiliki hasil negatif dalam jangka panjang, sehingga keseihmbangan jangka pendek akan mendorong keseimbangan jangka panjang. Dalam jangka panjang, krisis ekonomi mempengaruhi investasi swasta pada dan memiliki arah negatif.
\end{abstract}

Kata Kunci: Investasi Swasta; Model Koreksi Kesalahan; Ko-integrasi 


\section{PENDAHULUAN}

Investasi merupakan indikator yang dapat menentukan tingkat pertumbuhan ekonomi dalam perekonomian suatu negara. Pembangunan ekonomi di negara-negara berkembang (developing countries) termasuk didalamnya pertumbuhan ekonomi yang cukup tinggi, memiliki dana yang cukup besar. Menurut Indra Suhendra (2007), Investasi merupakan satu bagian penting dari pembangunan ekonomi, terutama dalam upaya meningkatkan pertumbuhan ekonomi. Melalui investasi, akan tersedia berbagai sarana produksi, yang dapat dioptimalkan dalam menghasilkan output dan nilai tambah sehingga akan meningkatkan pertumbuhan ekonomi. Dengan demikian, kegiatan investasi yang dilakukan merupakan indikator penting yang turut menentukan bagi kesinambungan dan keberhasilan pembangunan ekonomi.

Pada negara berkembang dan miskin, kondisi yang paling menonjol adalah belum terciptanya kondisi yang mendorong pada iklim dimana kegairahan untuk menabung dan penanaman modal menunjukan tingkat yang menggembirakan. Sistem produksi untuk meningkatkan pendapatan masyarakat masih menggunakan pola tradisional. Masih terbatasnya sektor modern dan belum berfungsinya secara efektif dan efisien institusi-institusi keuangan yang disebabkan oleh pola pikir masyarakat yang masih tradisional menyebabkan pengerahan dana dari masyarakat mengalami kesulitan.Investasi merupakan salah satu komponen yang penting dalam GNP. Di Indonesia, bagian dari investasi dalam produk domestik bruto masih relatip kecil, namun investasi tetap mempunyai peranan yang penting di dalam permintaan agregat. Pertama, biasanya pengeluaran investasi memiliki sifat yang tidak stabil sehingga mudah berfluktuasi dan dapat menyebabkan terjadinya resesi dan boom. Kedua, bahwa investasi sangat penting bagi pertumbuhan ekonomi serta perbaikan dalam produktivitas tenaga kerja. Pertumbuhan ekonomi sangat tergantung pada tenaga kerja dan jumlah (stock) dari kapital. Tanpa investasi maka tidak akan ada pabrik/mesin baru, dan dengan demikian tidak ada ekspansi.

Di negara sedang berkembang seperti Indonesia peranan pemerintah masih tergolong besar. Anggaran pemerintah sangat mempengaruhi kondisi 
perekonomian. Anggaran pemerintah dapat mempengaruhi tingkat output. Pengaruhnya tergantung kepada pengaruh anggaran terhadap kegiatan sektor swasta. Pengaruh anggaran pemerintah terhadap sektor swasta dapat bersifat substitusi atau komplementer. Anggaran pemerintah bersifat substitusi dengan sektor swasta jika investasi pemerintah bersaing dengan investasi swasta. Anggaran pemerintah dapat bersifat komplementer dengan sektor swasta apabila investasi pemerintah digunakan dalam pembangunan infrastruktur fisik maupun non fisik. Hal ini akan meningkatkan economies of scale melalui perluasan pasar yang selanjutnya akan meningkatkan keuntungan sektor swasta. Investasi pemerintah juga akan meningkatkan pendapatan secara langsung maupun tidak langsung melalui multiplier effect, sehingga sektor swasta akan terdorong untuk melakukan investasi karena keuntungan yang diperoleh akan meningkat sejalan dengan peningkatan pada permintaan terhadap barang akhir.

Krisis ekonomi yang melanda Indonesia pada pertengahan tahun 1997 yang kemudian menjadi krisis multidimensi berdampak kondisi Indonesia secara umum tidak hanya terhadap sektor ekonomi saja. Nilai tukar rupiah yang terdepresiasi sangat tajam, inflasi yang tinggi, menurunnya kepercayaan investor untuk berinvestasi di Indonesia, merupakan beberapa akibat dari krisis ekonomi tersebut. Lambat laun, dengan beberapa kali perubahan struktur politik dan penerapan kebijakan-kebijakan oleh pemerintah, kondisi Indonesia menunjukan perubahan yang lebih baik dan kondisi perekonomian yang stabil. Sebagai Negara yang memiliki jumlah penduduk yang sangat besar dengan letak yang sangat strategis, negara Indonesia merupakan wilayah yang potensial untuk menanamkan investasi. Dilihat dari sebarannya, investasi swasta di Indonesia sebagian besar terserap di sektor sekunder (industri pengolahan), kemudian diikuti oleh sektor tersier dan sektor primer.

Terkait dengan peran investasi (swasta maupun pemerintah) dalam mempengaruhi pertumbuhan ekonomi, secara umum telah lama menjadi pusat perhatian para ekonom. Dimulai dari Adam Smith, Solow, hingga ekonom terkini seperti David Romer. Perhatian tersebut menjadi kian intensif setelah ditemukannya fakta empiris bahwa tingkat investasi di sejumlah negara telah mampu mendorong peningkatan pertumbuhan ekonomi 
(selanjutnya disingkat pertumbuhan). Fenomena pengaruh investasi terhadap pertumbuhan ekonomi tersebut juga diduga terjadi di Indonesia. Dugaan tersebut dilihat dari besarnya kontribusi sektor industri pengolahan selaku kontributor terbesar terhadap pembentukan PDRB Nasional, yang mengalami pertumbuhan rata-rata sebesar 38,61 persen per tahun selama periode 1998 - 2005. Sedangkan sektor pertanian, yang merupakan sektor dominan di sebagian besar propinsi di Indonesia, justru mengalami penurunan rata-rata sebesar 1,94 persen per tahun pada periode yang sama.

Besarnya kontribusi industri pengolahan terhadap PDRB menandakan adanya pengaruh investasi swasta yang sebagian besar terserap di sektor industri (sekunder) dalam menciptakan peningkatan output dan nilai tambah bagi sektor tersebut. Oleh karenanya, dalam upaya menumbuhkan perekonomian, setiap wilayah (negara atau regional) senantiasa berusaha untuk dapat meningkatkan dan mendorong investasi. Sasaran yang dituju bukan hanya masyarakat atau kalangan swasta dalam negeri, tetapi juga investor asing. Begitupun dengan Negara Indonesia yang terus berusaha untuk meningkatkan investasi sebagai motor penggerak pembangunan ekonominya.

Pada saat investasi swasta dilakukan pada suatu wilayah di Indonesia, dampak yang diharapkan tentunya tidak semata-mata hanya untuk meningkatkan pertumbuhan ekonomi semata. Lebih dari itu, dampak investasi swasta diharapkan dapat menetes atau menjalar pada peningkatan kesempatan kerja dan distribusi pendapatan di wilayah atau daerah tersebut. Merupakan suatu hal yang lazim, apabila keberadaan investasi swasta diharapkan dapat memberikan pengaruh yang positif bagi kesempatan kerja di masing-masing wilayah, sehingga masyarakat dapat bekerja dan memperoleh pendapatan dari tambahan kesempatan kerja tersebut.

Investasi memegang peranan penting dalam meningkatkan pembangunan nasional dan sebagai salah satu komponen yang berhubungan positif dengan pertumbuhan ekonomi. Sukses tidaknya suatu negara dalam menarik arus dana investasi tidak terlepas dari berbagai faktor ekonomi dan non ekonomi. Pada dasarnya pemberian fasilitas yang sifatnya mendorong investor untuk berinvestasi seperti pembebasan pajak (tax holiday) dan 
kemudahan untuk mengakses bahan baku akan sangat efektif bila didukung oleh negara tujuan investasi memiliki keunggulan komparatif ekonomi yang berkaitan dengan faktor-faktor produksi seperti sumber daya alam dan sumber daya manusia yang terampil dan murah, nilai tukar yang relatif stabil, terutama untuk investor yang berorientasi pasar luar negeri, peraturan devisa di negara bersangkutan tidak menghalangi penanam modal untuk memindahkan kekayaan dan keuntungannya ke luar negeri, iklim politik dan keamanan negara cukup menjamin ketentraman hidup dan keamanan usaha serta kekayaan investor, iklim usaha yang menunjang dan mendorong penanaman modal, infrastruktur yang menunjang dan memadai.

Berdasarkan latar belakang dan dalam kaitannya dengan stabilisasi untuk mengatasi akibat buruk dari adanya fluktuasi investasi maka rumusan masalah dapat diidentifikasi adalah factor-faktor apa saja yang mempengaruhi investasi swasta di Indonesia pada periode penelitian. Hasil penelitian ini diharapkan dapat berguna dan bermanfaat: Sebagai masukan bagi pengambil kebijakan dalam upaya menggerakkan dan mendorong investasi swasta di Indonesia. Diharapkan dapat menjadi rekomendasi bagi pengambil kebijakan untuk merancang kebijakana dalam mengelola variabel ekonomi yang dapat berpengaruh pada pertumbuhan ekonomi, kesempatan kerja dan distribusi pendapatan. Bagi ilmu pengetahuan, penelitian ini diharapkan dapat digunakan sebagai bahan literatur dan referensi.

\section{METODE}

Data yang digunakan dalam kajian ini adalah data tahunan dari tahun 1990 sampai tahun 2008. Kajian ini menggunakan Investasi Swasta sebagai variable terikat (dependent variable), Pendapatan Nasional, Investasi Pemerintah, Tingkat Inflasi, dan Suku Bunga sebagai variable bebas (dependent variable), serta variabel dummy krisis ekonomi Indonesia. Kajian ini menggunakan pendekatan kointegrasi dan Error Correction Model (ECM). Pendekatan kointegrasi bertujuan untuk melihat hubungan keseimbangan jangka panjang antara variabel-variabel dalam model. Sedangkan pendekatan ECM bertujuan untuk melihat dinamika jangka pendek dari variabel-variabel dalam model yang mengarahkan kepada keseimbangan 
jangka panjangnya. Disamping itu akan dilakukan pengujian-pengujian terhadap masalah yang biasa muncul dalam regresi linier dan analisis runtun waktu (time series).

Dalam analisis statistika, akan diperlihatkan sampai sejauh mana validitas model yang digunakan dalam penelitian melalui pengujian secara statistik terhadap model yang bersangkutan. Pengujian masalah-masalah linier ditujukan untuk menghasilkan model regresi dan hasil estimasi yang akurat dan tidak bertentangan dengan asumsi regresi linear klasik. Pengujian tersebut meliputi perhitungan t-statistik dan F-statistik, penaksiran koefisien determinasi dan Durbin Watson statistik.

Salah satu asumsi yang terdapat pada analisa regresi yang melibatkan data time series adalah data yang diamati bersifat stasioner. Data stasioner adalah data yang menunjukkan mean, varians, dan autovarians (pada variasi lag) tetap sama pada waktu kapan saja data itu dibentuk atau dipakai, artinya suatu data disebut stasioner jika perubahannya stabil. Apabila data yang digunakan dalam model ada yang tidak stasioner, maka data tersebut harus dipertimbangkan kembali kevalidan dan kestabilanya, karena hasil regresi yang berasal dari data yang tidak stasioner akan menyebabkan spurious regression (regresi lancung). Spurious regression adalah regresi yang memiliki $R^{2}$ yang tinggi melebihi nilai Durbin-Watson stat. Masalah ini muncul karena indikasi trend yang kuat, jadi $\mathrm{R}^{2}$ yang tinggi itu disebabkan oleh keberadaan trend tersebut, bukan karena hubungan ekonomi. Sementara nilai D-W stat yang kecil merefleksikan residual tidak stasioner. Salah satu konsep yang dipakai untuk menguji kestasioneran data time series adalah uji akar unit (unit root test).

Di dalam penelitian ini akan digunakan uji akar unit melalui uji DickeyFuller (DF-Test) untuk mengetahui apakah data time series yang digunakan memiliki masalah akar unit atau data tidak stasioner. Jika suatu data time series tidak stasioner pada order nol, I(0), maka stasionaritas data tersebut bisa dicari melalui berbagai order sehingga diperoleh tingkat stasionaritas pada order ke-n (first difference atau I(1), atau second difference atau I(2), dan seterusnya). Persamaan regresi tanpa intercept yang digunakan pada pengujian ini adalah sebagai berikut : 


$$
Y_{t}=\rho Y_{t-1}+u_{t} \text { atau }
$$

$$
\Delta \mathrm{Y}_{\mathrm{t}}=\delta \mathrm{Y}_{\mathrm{t}-1}+\mathrm{u}_{\mathrm{t}}
$$

$\Delta=$ first difference dari variabel yang digunakan

$\mathrm{t}=$ variabel trend

$\delta=\rho-1$, jika $\rho=1$, terdapat unit root, tidak stasioner.

Hipotesis untuk pengujian ini adalah :

$\mathrm{H}_{0}: \delta=0$ (terdapat unit roots, tidak stasioner)

$\mathrm{H}_{1}: \delta \neq 0$ (tidak terdapat unit roots, stasioner)

\section{HASIL DAN PEMBAHASAN}

Berdasarkan hasil uji akar unit dengan berpatokan pada nilai batas kritis Dickey-Fuller dan hasil hipotesis di atas, maka dapat diambil hasil kesimpulan uji akar unit dalam Tabel 1. Dari Tabel 1 dapat dilihat, setelah dilakukan first difference dari data penelitian, terlihat $\mathrm{t}-\mathrm{DF}<\mathrm{t}$-kritis. Ini berarti bahwa variabel Investasi Swasta stasioner pada tingkat $\alpha=5 \%$ dan terintegrasi pada order I (1).

Model kointegrasi digunakan untuk menganalisis apakah trend dari nilai variabel tak bebas bergerak dengan arah yang sama dengan trend variabel bebasnya, sehingga tercapai keseimbangan jangka panjang. Untuk mendapatkan nilai residual term yang akan diuji kointegrasi dilakukan regresi persamaan linier dengan berdasarkan asumsi kenormalan "Model Regresi Linier Normal Klasik".

\begin{tabular}{|c|c|c|c|c|}
\hline Level & Variabel & $\begin{array}{l}\text { ADF test } \\
\text { statistik }\end{array}$ & Kesimpulan & $\alpha$ \\
\hline \multirow{5}{*}{$\begin{array}{c}\text { First } \\
\text { difference }\end{array}$} & Ln INVS & -2.561 & Stasioner pada I(1) & $5 \%$ \\
\hline & Ln YN & -1.633 & Tidak Stasioner & - \\
\hline & Ln INVP & -5.44 & $\begin{array}{c}\text { pada I(1) } \\
\text { Stasioner pada I(1) }\end{array}$ & $1 \%$ \\
\hline & Ln INF & -4.814 & Stasioner pada I(1) & $1 \%$ \\
\hline & Ln IR & -3.241 & Stasioner pada I(1) & $1 \%$ \\
\hline
\end{tabular}

\section{Tabel 1. Hasil Pengujian Unit Root}

Sumber: Hasil penghitungan 
Perlu dilakukan pengujian kointegrasi yang dimaksudkan untuk mengetahui apakah terjadi keseimbangan dalam jangka panjang pada model yang digunakan dengan cara menguji stasionaritas residual atau error term dari model tersebut, melalui metode Engle-Granger (pendekatan Dicky Fuller Test). Persamaan yang digunakan untuk tes kointegrasi adalah persamaan Dickey Fuller Regression:

$\Delta \mathrm{Y}_{\mathrm{t}}=(\delta-1) \mathrm{Y}_{\mathrm{t}-1}+\mathrm{U}_{\mathrm{t}}$

Hipotesis untuk pengujian ini adalah :

$\mathrm{H}_{0}: \delta=0$ (variabel-variabel dalam model tidak terkointegrasi)

$\mathrm{H}_{1}: \delta \neq 0$ (variabel-variabel dalam model terkointegrasi)

Pada tingkat kepercayaan 99\% hasil regresi memiliki variabel-variabel yang terkointegrasi pada derajat $\mathrm{I}(0)$. Hal tersebut menunjukkan bahwa residual dari kedua model kointegrasi tersebut terkointegrasi. Artinya hasil regresi memiliki derajat integrasi yang sama (terkointegrasi), di mana variabel variabel bebas dalam model persamaan memiliki pengaruh hubungan jangka panjang dengan variabel tak bebasnya (terikat).

Koefisien determinasi $\left(R^{2}\right)$ mencerminkan besarnya pengaruh perubahan variabel bebas (independent variables) dalam menjelaskan perubahan pada variabel tidak bebas / variabel terikat (dependent variables) secara bersama-sama, dengan tujuan untuk mengukur kebenaran dan kebaikan hubungan antar variabel dalam model yang digunakan. Besarnya nilai koefisien determinasi adalah antara 0 hingga $1\left(0<R^{2}<1\right)$, dimana nilai koefisien mendekati 1, maka model tersebut dikatakan baik karena semakin dekat hubungan antara variabel bebas dengan variabel tidak bebasnya. Hasil estimasi model kointegrasi persamaan investasi swasta menunjukkan nilai koefisien determinasi $\left(R^{2}\right)$ sebesar 0,965 . Artinya $96 \%$ perubahan variabel investasi swasta pada jangka panjang dipengaruhi oleh variabel-variabel penentu dalam model, sedangkan sisanya $4 \%$ diterangkan oleh variabel lain yang tidak dimasukkan dalam model.

Hasil uji t-statistik pada persamaan dinamis model investasi swasta adalah sebagai berikut (lihat table 4.2) 
Tabel 2. Hasil Uji Statistik - t Model Kointegrasi

\begin{tabular}{cccc}
\hline Variabel & Statistik -t & $\alpha$ & Kesimpulan \\
\hline Ln INVS & $-12,26$ & $1 \%$ & Signifikan \\
Ln YN & 20,65 & $1 \%$ & Signifikan \\
Ln INVP & $-1,81$ & $10 \%$ & Signifikan \\
Ln INF & $-1,81$ & $10 \%$ & Signifikan \\
Ln IR & $-0,24$ & - & Tidak Signifikan \\
Dummy & $-52,83$ & $1 \%$ & Signifikan \\
\hline
\end{tabular}

Sumber: Hasil perhitungan

Uji F-statistik untuk mengukur goodness of fit dari persamaan regresi, yaitu pengaruh variabel bebas secara bersama-sama terhadap pergerakan variabel tidak bebasnya. Dengan demikian hasil uji $\mathrm{F}$ yang signifikan akan menunjukkan bahwa variabel bebas secara bersama-sama memiliki pengaruh terhadap variabel tidak bebasnya. Uji F-stat ini merupakan uji signifikansi satu arah (one tail significance). Model investasi swasta mempunyai nilai F-hitung sebesar 125,237 persamaan ini terbukti signifikan pada confidence level $1 \%$ karena lebih besar dari F-tabel sebesar 4,69. Dengan kata lain, variabel pendapatan nasional, investasi pemerintah, tingkat inflasi, suku bunga, dan dummy variable krisis ekonomi secara bersama-sama signifikan mempengaruhi arah investasi swasta pada tingkat kepercayaan $99 \%$.

Multikolinear menunjukan gejala adanya hubungan linear atau hubungan yang pasti diantara eksplanatori variabel (variabel penjelas) dalam model regresi. Gejala ditunjukkan oleh beberapa faktor, namun yang paling mendukung penjelasan adanya multikolinier dalam model yaitu apabila nilai $\mathrm{R}^{2}$ dari hasil regresi sangat tinggi namun sebagian besar eksplanatori variabel tidak menjelaskan hubungan yang signifikan terhadap variabel yang dijelaskan, melalui perbandingan antara nilai t-stat dan F-stat dengan t-tabel dan F-tabel. Berdasarkan ciri-ciri adanya gejala multikolinier dalam model, maka dengan melihat hasil regresi sudah cukup untuk menyimpulkan tidak adanya masalah multikolinier dalam model.

Serial korelasi dapat didefinisikan sebagai korelasi di antara anggota serangkaian observasi yang diurutkan menurut waktu. Untuk mendeteksi ada tidaknya masalah ini dalam suatu model, ada dua metode yang biasanya digunakan yaitu dengan menggunakan uji Durbin-Watson atau dengan uji run. 
Pengujian run biasanya untuk menyimpulkan apabila pada pengujian DurbinWatson didapat hasil "tidak ada kesimpulan". Hasil autokorelasi didalam model investasi swasta masih berada di daerah ragu-ragu sehingga tidak ada keputusan apakah terjadi autokorelasi atau tidak, jadi persamaan harus diuji lebih lanjut dengan Run Test.

Uji run dilakukan dengan melakukan perhitungan terhadap pergerakan residual yang diperoleh dari selisih nilai aktual dari variabel tak bebasnya terhadap nilai estimasinya. Setelah dilakukan pengujian run pada persamaan, ternyata nilai run $(\mathrm{K})$ berada pada daerah Ho yang tidak ditolak, yaitu diantara daerah kritis atas dan daerah kritis bawah, ini berarti tidak terdapat autokorelasi pada persamaan diatas pada tingkat kepercayaan $99 \%$.

Dari hasil regresi yang telah dijelaskan sebelumnya dapat diketahui bahwa sebagian besar variabel-variabel bebas secara signifikan berpengaruh terhadap investasi swasta di Indonesia. Dari uji kointegrasi di hasilkan kesimpulan bahwa terjadi keseimbangan dalam jangka panjang pada kedua model yang digunakan. Selanjutnya akan diuraikan satu persatu mengenai berapa besar pengaruh dari masing-masing variabel bebas terhadap variabel tak bebasnya.

Dari hasil regresi diperoleh hasil bahwa dalam jangka panjang variabel pendapatan riil berpengaruh positif terhadap investasi swasta Indonesia, dimana setiap kenaikan pendapatan riil sebesar $1 \%$, ceteris paribus, akan menambah tingkat investasi swasta sebesar 1,64\%. Pengaruh positif ini sudah sesuai dengan teori baik teori klasik maupun teori Keynes. Keduanya menyatakan bahwa tingkat investasi tergantung dari pendapatan. Makin tinggi tingkat pendapatan, maka investasi sebagai salah satu komponen dalam perhitungan pendapatan nasional juga akan meningkat.

Variabel investasi pemerintah memiliki korelasi yang negative, hal ini berarti, kenaikan $1 \%$ rasio investasi pemerintah terhadap PDB akan menyebabkan investasi swasta mengalami penurunan sebesar 0,31\%, ceteris paribus. Terjadinya hubungan negatif antara investasi pemerintah dengan tingkat investasi swasta kemungkinan besar berkaitan dengan masalah alokasi dan efisiensi penggunaan dana untuk investasi, yang pada akhirnya menyebabkan terjadinya Crowding Out pada sektor swasta. Dimana 
pemerintah ingin menaikkan tingkat investasinya melalui penerbitan obligasi sehingga dana dari masyarakat mengalir ke sektor pemerintah dikarenakan adanya jaminan dan resiko yang lebih kecil dibandingkan sektor swasta. Mengalirnya dana ke sektor pemerintah, menyebabkan berkurangnya dana bagi sektor swasta, sehingga investasi sektor swasta berkurang.

Koefisien dari variabel tingkat inflasi menunjukkan bahwa dalam jangka panjang hubungan antara tingkat inflasi dengan investasi swasta adalah negatif dimana setiap kenaikan tingkat inflasil sebesar $1 \%$ akan menyebabkan penurunan tingkat investasi swasta sebesar $0,018 \%$. Hal ini sudah sesuai dengan teori bahwa dampak inflasi terhadap investasi swasta bisa positif atau negatif. Ternyata berdasarkan hasil yang diperoleh, pada jangka panjang inflasi berdampak negatif menurunkan tingkat investasi swasta meskipun dampaknya tidak terlalu besar.

Berdasarkan hasil regresi, koefisien variabel krisis ekonomi bernilai 0,52 dan secara statistik signifikan pada tingkat kepercayaan 99\%. Nilai itu menunjukkan bahwa dalam jangka panjang dummy variable krisis ekonomi berpengaruh negatif terhadap tingkat investasi swasta Indonesia. Ketika terjadi krisis ekonomi, berbagai perubahan terjadi pada kondisi perekonomian Indonesia, dan mendorong kepada keadaan yang lebih buruk daripada sebelum krisis.

Model persamaan dinamis dimaksudkan untuk mengetahui pengaruh perubahan berbagai variabel independen terhadap perubahan variabel dependennya dalam jangka pendek. Model ini digunakan untuk mengetahui bagaimana ketidakseimbangan jangka pendek yang digambarkan dengan variablel first difference-nya dikoreksi atau disesuaikan untuk mencapai keseimbangan jangka panjangnya yang digambarkan dengan signifikansi dari variabel error correction term-nya. Dalam analisis mengenai investasi swasta diperlukan juga proses penyesuaian dinamis yang disebut mekanisme koreksi eror (Error Correction Mechanism) yang akan menunjukkan ada atau tidaknya keseimbangan dalam jangka pendek dari suatu model.

Model dinamis investasi swasta pada jangka pendek memiliki $R^{2}$ sebesar 0,935 yang berarti bahwa varians dari variabel bebas didalam model 
ini dapat menerangkan $93,5 \%$ dari variabel tidak bebasnya, sedangkan sisanya sebesar $20 \%$ dipengaruhi oleh variabel lain diluar model.

Hasil uji t-statistik pada persamaan dinamis model investasi swasta adalah sebagai berikut (lihat Tabel 3)

Tabel 3. Hasil Uji Statistik - $t$ Model Dinamis

\begin{tabular}{cccc}
\hline Variabel & Statistik $\mathbf{- t}$ & $\boldsymbol{\alpha}$ & Kesimpulan \\
\hline Ln INVS & $-2,42$ & $5 \%$ & Signifikan \\
Ln YN & 3.61 & $1 \%$ & Signifikan \\
Ln INVP & $-2,75$ & $5 \%$ & Signifikan \\
Ln INF & -2.71 & $5 \%$ & Signifikan \\
Ln IR & $-1,24$ & - & Tidak Signifikan \\
Dummy & -1.22 & - & Tidak Signifikan \\
ECT $(-1)$ & -3.27 & $1 \%$ & Signifikan \\
\hline
\end{tabular}

Sumber: Hasil perhitungan

Persamaan model dinamis investasi swasta di Indonesia mempunyai nilai F-hitung sebesar 52,874. Persamaan ini terbukti signifikan pada confidence level $1 \%$ karena lebih besar dari F-tabel yaitu 4,46. Dengan kata lain, variabel-variabel first difference pendapatan nasional dispisibel riil, tingkat suku bunga deposito riil, tingkat inflasi, dummy variable krisis ekonomi, dan faktor koreksi kesalahan (error) secara bersama-sama signifikan mempengaruhi arah variabel first difference investasi swasta di Indonesia pada $\alpha=0.01$.

Berdasarkan hasil uji t-statistik persamaan model dinamis investasi swasta di Indonesia, hanya variabel first difference tingkat suku bunga tidak signifikan tetapi memiliki nilai R2 yang cukup tinggi, sehingga dapat dikatakan bahwa model dinamis investasi swasta yang digunakan tidak terdapat masalah multikolinearitas. Hasil pengujian autokorelasi di dalam model dinamis investasi swasta berada di daerah tidak terdapat autokorelasi, sehingga dapat disimpulkan bahwa pada model dinamis investasi swasta tidak terdapat masalah autokorelasi.

Hasil estimasi menunjukkan bahwa error correction term $\left(\mathrm{EC}_{\mathrm{t}-1}\right)$ untuk model dinamis investasi swasta signifikan pada tingkat kepercayaan $99 \%$. Hal ini berarti bahwa terjadi koreksi penyesuaian perubahan jangka pendek 
kembali ke keseimbangan jangka panjangnya atau dengan kata lain bahwa ketidakseimbangan (disequilibrium) disuatu periode akan dikoreksi pada periode berikutnya. Koefisien $\mathrm{EC}_{\mathrm{t}-1}$ yang negatif berarti pada jangka pendek, model tersebut berada dibawah keseimbangan jangka panjangnya, sehingga proses penyesuaian keseimbangan jangka pendek menuju ke keseimbangan jangka panjang arahnya bergerak keatas.

Hubungan antara pendapatan riil dan investasi swasta pada jangka panjang hampir sama dengan jangka pendeknya, pada jangka pendek variabel first difference pendapatan riil secara statistik signifikan mempengaruhi investasi swasta di Indonesia. Koefisien sebesar 4,32 menunjukkan bahwa dalam jangka pendek, nilai tersebut signifikan secara statistik pada tingkat kepercayaan 99\%. Seperti pada jangka panjang, pendapatan nasional riil mempunyai korelasi positif dengan tingkat investasi swasta. Namun pada jangka pendek perubahan pendapatan nasional riil mempunyai dampak lebih besar daripada jangka panjang. Hal ini berarti perubahan tersebut direspon oleh masyarakat secara seketika.

Variabel fist difference investasi pemerintah memiliki korelasi yang negatif dengan tingkat investasi swasta dengan nilai koefisien sebesar -0,26. Terjadinya hubungan negatif antara investasi pemerintah dengan tingkat investasi swasta sama seperti pada jangka panjangnya kemungkinan besar berkaitan dengan masalah alokasi dan efisiensi penggunaan dana untuk investasi, yang pada akhirnya menyebabkan terjadinya Crowding Out pada sektor swasta. Tetapi pada jangka pendek pengaruhnya lebih kecil karena terjadinya proses penyesuaian terhadap kondisi jangka panjangnya.

Hubungan antara tingkat inflasi dan investasi swasta pada jangka panjang hampir sama dengan jangka pendeknya, pada jangka pendek variabel first difference pendapatan riil secara statistik signifikan mempengaruhi investasi swasta di Indonesia pada tingkat kepercayaan 95\%. Koefisien sebesar -0,0096 menunjukkan bahwa dalam jangka pendek, setiap kenaikan tingkat inflasi sebesar $1 \%$, cateris paribus akan menurunkan investasi swasta sebesar 0,0096\%. Seperti halnya pada jangka panjang, pengaruh tingkat inflasi pada jangka pendek tidak terlalu besar terhadap investasi swasta. Tetapi meskipun demikian, inflasi pada jangka pendek 
menyebabkan penurunan pada investasi swasta karena tingginya risiko yang disebabkan karena inflasi.

\section{SIMPULAN}

Hasil uji kointegrasi menunjukkan bahwa variabel-variabel penentu dalam model dengan investasi swasta terkointegrasi, artinya dalam jangka panjang pergerakan variabel bebas searah dengan variabel tidak bebas. Pengujian akar unit (Dickey-Fuller Test) membuktikan bahwa variabel-variabel dalam model terintegrasi pada orde yang sama, yaitu $\mathrm{I}(1)$ dan memenuhi syarat stasioneritas, sehingga dapat dipastikan bahwa pada model kointegrasi investasi swasta tidak terjadi spurious regression.

Berdasarkan uji statistik Error-Correction Model (ECM) investasi swasta, koefisien variabel pendapatan nasional riil pada jangka pendek berpengaruh signifikan dan mempunyai tanda positif. Koefisien variabel tingkat suku bunga riil secara statistik mempunyai hubungan negatif tetapi pengaruhnya tidak signifikan Koefisien variabel tingkat inflasi secara statistik signifikan dan mempunyai tanda negatif. Koefisien variabel rasio investasi pemerintah terhadap PDB secara statistik signifikan pada tingkat kepercayaan 99\% dan mempunyai tanda negatif. Koefisien variabel error-correction term $\left(E C T_{t-1}\right)$ secara statistik signifikan pada tingkat kepercayaan $99 \%$ dan mempunyai tanda negatif. Koefisien variabel $\mathrm{ECT}_{\mathrm{t}-1}$ yang negatif berarti model tersebut pada jangka pendek berada dibawah keseimbangan jangka panjangnya, sehingga proses penyesuaian keseimbangan jangka pendek menuju ke keseimbangan jangka panjang arahnya bergerak keatas.

Pada jangka panjang koefisien variabel krisis ekonomi secara statistik signifikan mempengaruhi investasi swasta pada tingkat kepercayaan masingmasing 90\% dan 99\% dengan tanda negatif. Sedangkan pada jangka pendek koefisien variabel krisis ekonomi berpengaruh negatif dan signifikan terhadap investasi swasta. 


\section{PUSTAKA ACUAN}

Agrawal, P. 2001. Interest Rates and Investment Levels: An Empirical Evaluation of McKinnon, Stiglitz, and Neo-Structaralist Hypotheses. Journal of Economic 0110, March, pp. 1-29

Barro, Robert J. \& Sala-i-Martin. 1992. Public Finance in Models of Economic Growth. Review of Economic Studies 59 (201).

Blank, Rebecca M. \& Esaki Albert. 1978. Macroeconomic Activity and Income Distribution in the Postwar United States. Working Paper No. 1267, 1985

Djuhari M. Wirakartakusumah. 1998. Bayang-Bayang Ekonomi Klasik. Direktorat Jenderal Pendidikan Tinggi Departemen Pendidikan dan Kebudayaan. Jakarta

Gujarati, Damodar. 2003. Basic Econometrics. $4^{\text {th }}$ Edition, Singapore: McGraw-Hill International Editions

Jhingan, M.L. 1999. Ekonomi Pembangunan dan Perencanaan. Jakarta: Raja Grafindo Persada.

Jayaraman, T.K. dan Baljeet Singh. 2007. Foreign Direct Investment and Employment Creation in Pacific Island Countries: An empirical study of Fiji. Working Paper Series, No. 35, May, pp. 33 - 65

Jhingan, H.L. 2000. Development Planning. Singapore: The Mc.Graw-Hill Companies. Inc

Jongwanich, Juthathip. \& Archanun Kohpaiboon. 2006. Private Investment: Trends and Determinants in Thailand. Journal of Economics 0970, December, pp. 1-29

Khan, Sajawal. \& Muhammad Arshad Khan. 2007. What Determines Private Investment? The Case of Pakistan. PIDE Working Papers 2007:36

Le, Quan V. 2004. Political and Economic Determinants of Private Investment. Journal of International Development 16. pp. 589-604.

Lesotlho, Patrick. 2006. An Investigation of the Determinants of Private Investment: The Case of Botswana. Policy Research Working Paper No. 2123, pp. $11-34$.

Mankiw, N. Gregory. Principles of Economics. New York: Mcgraw-Hill. Mankiw, N. Gregory. 2000. Macroeconomics. New York : Mcgraw-Hill. 
Serven, Luis. Real Exchange Rate Uncertainty and Private Investment in Developing Countries. World Bank.

Sturm, Jan-Egbert. \& Gerard H. Kuper. \& Jakob de Haan. 1996. Modelling Government Investment and Economic Growth on a Macro Level: a Review. CCSO Series No. 29, September, pp. 24-62

Todaro, Michael P. \& Stephen C. Smith. 2003. Economic Development. New York: The Addison-Wesley.

Tulus Tambunan. 2003. Perekonomian Indonesia: Beberapa Masalah Penting. Jakarta: Ghalia Indonesia

Valila, Timo. \& Aaron Mehrotra. 2005. Evolution and Determinants of Public Investment in Europe. Economic and Financial Report 2005/01, pp. 1 37 